\title{
A. JEANROY
}

\section{LES TROUBADOURS EN RSPAGNE}

(Extrait des Annales du Midi. - Tome XXVII.)

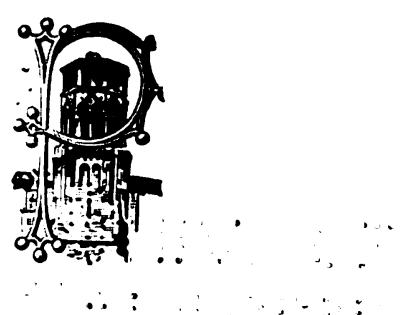

\section{TOULOUSE}

IMPRIMERIE ET LIBRAIRIE ÉDOUARD PRIVAT Librairie de l'Université.

14, RUR des ARTS (SQUARE dU MUSÉE)

1916 